\title{
Structural Particularities of the Epithelium Lining the Lamb Epiglottis
}

\author{
Vasile RUS ${ }^{1}$, Flavia RUXANDA ${ }^{1 *}$, Bianca MATOSZ ${ }^{1}$, Cristian RAŢIU ${ }^{2}$, Adrian GAL ${ }^{1}$, Viorel MICLĂUȘ ${ }^{1}$ \\ ${ }^{1}$ Faculty of Veterinary Medicine, USAMV Cluj-Napoca, Romania. \\ ${ }^{2}$ Faculty of Medicine and Pharmacy, University of Oradea, Romania. \\ *corresponding author: flavia.ruxanda@gmail.com
}

Bulletin UASVM Veterinary Medicine 73(2) / 2016,

Print ISSN 1843-5270; Electronic ISSN 1843-5378

DOI:10.15835/buasvmcn-vm: 12183

\begin{abstract}
Epiglottis presents a central axis covered by mucosa. The aim of this study was highlighting the type of epithelium lining the lamb epiglottis. Thus, we histologically processed the epiglottis from 3 lambs. The epithelium lining the whole epiglottis surface is non-keratinized stratified squamous, with different thickness from one side to the other. Hence, on the pharyngeal side the epithelium is twice as thick as the one found on the laryngeal side.
\end{abstract}

Keywords: epiglottis, epithelium, lamb

\section{INTRODUCTION}

Epiglottis presents a central axis formed out of elastic cartilage and dense irregular connective tissue with numerous seromucous glands (Raica et al., 2004; Miclăuş, 2012). This central ax is lined by epithelium, which is non-keratinized stratified squamous on the pharyngeal side and respiratory type (cilliated pseudostratified columnar) on the laryngeal one, according to some authors (Rüedi, 1959; Diculescu et al., 1971; Aughey and Frye, 2001; Raica et al., 2004; Gal and Miclăuș, 2013). Other authors (Junqueira et al., 1992) claim that squamous stratified epithelium covers the whole pharyngeal side and the apical portion of the laryngeal side and changes to cilliated pseudostratified columnar towards the base of the epiglottis on the laryngeal side.

\section{AIMS AND OBJECTIVES}

Due to the fact that the information present in the specialty literature we consulted is uneven, we set out to highlight the type of epithelium lining the epiglottis in lambs.

\section{MATERIAL AND METHODS}

We harvested samples from the epiglottis of 3 hybrid Merino lambs being approximately 3 month old, sacrificed by breeders for own consumption. The slices had a $3 \mathrm{~mm}$ thickness and were oriented in a sagittal plan through epiglottis. These fragments were fixed in Stieve's solution for 24 hours long, dehydrated in ethanol, clarified in butanol and embedded in paraffin. Afterwards, we sectioned the samples at a $5 \mu \mathrm{m}$ thickness and stained them with Goldner's trichrome method for contrast.

\section{RESULTS AND DISCUSSIONS}

The epithelium lining the whole surface of the epiglottis (harvested from the 3 lambs) is nonkeratinized stratified squamous epithelium (Fig. 1) and three layers can be observed: basal, stratum spinosum and squamous. Concerning the thickness of the epithelium, there are significant differences between the two sides of the epiglottis. Thus, on the pharyngeal side, the epithelium is almost twice as thick as the one on the laryngeal side. Moreover, 


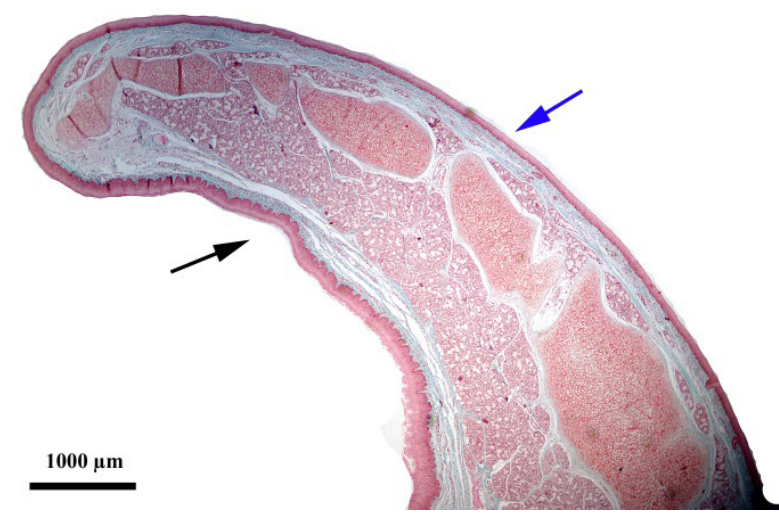

Fig. 1 Epiglottis - overview

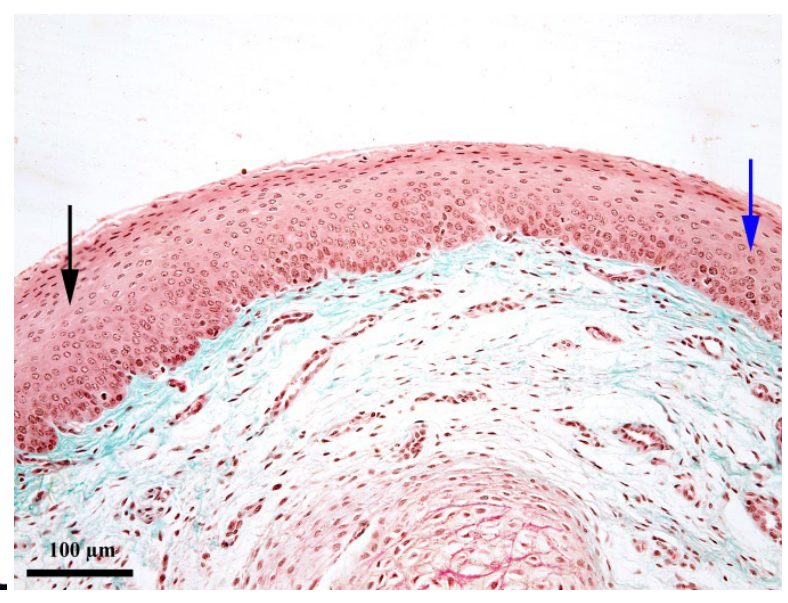

Fig. 2 Epiglottis - detail from epiglottis apex Goldner's trichrome, black arrow - pharyngeal side; blue arrow - laryngeal side

the basement membrane of the epithelium lining the pharyngeal side is curved, with large amplitude and high density folds. Towards the free end of the epiglottis, the epithelium becomes thinner and at the same time, the amplitude and density of the folds become smaller and smaller (Fig. 2). On the laryngeal side, the epithelium becomes thinner and the folds of the basement membrane become more faded. From place to place, there are few taste buds present, but only in the epithelium lining the laryngeal side.

In the depth of lamina propria, we observed seromucous glands on the examined slides, but we did not notice any excretory ducts opening on the pharyngeal side of the epiglottis, only on the laryngeal one.

The obtained results differ from the ones signaled by other authors, especially in humans (Diculescu et al., 1971; Raica et al., 2004), but also in animals (Aughey and Frye, 2001; Miclăus, 2012; Gal and Miclăuș, 2013) and partially resemble the ones described by Junqueira et al. (1992) who state that the epithelium lining the whole laryngeal surface of epiglottis is stratified squamous. The presence of taste buds in epiglottis was also mentioned by other authors (Diculescu et al., 1971; Sweazey et al., 1994; Aughey and Frye, 2001; Raica et al., 2004) both in humans and animals, but the information regarding their location is either not precise or contradictory. Thus, Diculescu et al. (1971) does not specify the side of the epiglottis they are encountered, while Raica et al. (2004) sustain that in humans, taste buds can only be found on the pharyngeal side. The information regarding the presence and localisation of the taste buds in the epithelium lining lamb epiglottis, is similar to the one described by Aughey and Frye (2001) in animals.

\section{CONCLUSIONS}

In lambs, the epithelium lining the epiglottis is non-keratinized stratified squamous and on the pharyngeal side is almost twice as thick as the one on the laryngeal side. The basement membrane's folds on the pharyngeal side are denser and more ample in comparison to those on the laryngeal side.

\section{REFERENCES}

1. Aughey E, Frey FL (2001). Comparative veterinary histology whith clinical correlates, Manson Publishing, London.

2. Diculescu I, Onicescu D, Rimniceanu C, Histologie, Partea a III-a, Editura didactică și pedagogică, București, 1971.

3. Gal AF, Miclăuș V (2013). Histology, Editura Risoprint, Cluj-Napoca.

4. Miclăuș V (2012). Histologie specială și embriologie generală, ediția a II-a, Editura Risoprint, Cluj-Napoca.

5. Raica M, Mederle O, Căruntu ID, Pintea A, Chindriș AM (2004). Histologie teoretică și practică, Editura Brumar, Timișoara.

6. Rüedi L (1959). Some observations on the histology and function of the larynx, The Journal of Laryngology \& Otology 73(1), 1-20.

7. Sweazey RD, Edwards CA, Kapp BM (1994). Fine Structure of Taste Buds Located on the Lamb Epiglottis, The Anatomical Record, 238, 517-527. 